\title{
Beyond arbitrary interference: the right to a home? Developing socio-economic duties in the European Convention on Human Rights
}

\author{
Dr Ellie Palmer*
}

School of Law, University of Essex

\begin{abstract}
$\underline{\text { Abstract }}$
This paper is concerned with divergent trends in the protection of socio-economic rights by the European Court of Human Rights (ECtHR). It focuses on the potential to gain access to housing or housing-related benefits through the incremental development of positive obligations in the European Convention on Human Rights (ECHR). First, it argues that, despite the conceptual inadequacy of the positive-negative dichotomy of rights, its influence is still strongly reflected in the ECtHR's jurisprudence. It demonstrates that, despite the potential to develop the positive aspects of Articles 3 and 8 ECHR to protect vulnerable homeless individuals in respect of their need for shelter, strategic successes of the past decade, such as Connors $v$ $\mathrm{UK}^{1}$ and McCann $v \mathrm{UK},{ }^{2}$ reflect a bias towards claims involving negative interference with the enjoyment of an existing home. Second, the article considers the implications of a trend towards the harmonisation of socio-economic rights in member states, through use of the fair trial right in Article 6, or the right to equal treatment in Article 14, read with Article 1 of Protocol 1 ECHR. It argues that, despite the impression of progress in Tsfayo $v \mathrm{UK}^{3}$ and Stec $v \mathrm{UK},{ }^{4}$ the ECtHR has relied on an artificial extension of substantive rights to a fair trial or to property covered by the Convention, rather than on efforts to address issues of socio-economic disadvantage more holistically through the development of a principled jurisprudence of positive obligations in the ECHR.
\end{abstract}

\section{Introduction}

$\mathrm{D}$ uring the past two decades, individuals and groups have increasingly tested the extent to which governments and public authorities might be held to account through the judicial system for failing to provide access to health and welfare services or the financial means to acquire them. ${ }^{5}$ The ECtHR has not escaped this trend. It has increasingly been faced with questions from national courts concerning the boundaries of state responsibilities for meeting basic human needs, such as life-prolonging treatment for terminally ill patients and facilities to increase the ability of people with disabilities to live a

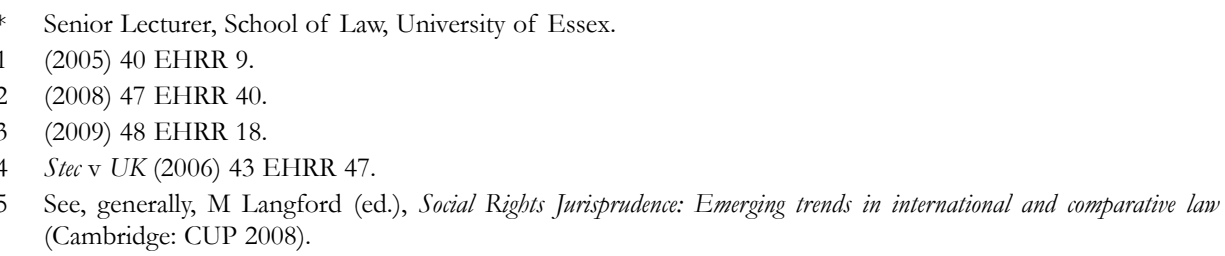


fulfilling life in the community, or for making basic provision, including shelter, for those who have suffered extreme deprivations or psychological injury as a result of conduct by the state, its agents, or third parties. ${ }^{6}$ Moreover, in recent cases, there have been strategic victories in gaining access to economic social security benefits ${ }^{7}$ of the kind protected by Article 9 of the International Covenant on Economic, Social and Cultural Rights (ICESCR) or by Article 12 of the European Social Charter (ESC). ${ }^{8}$ Furthermore, it is notable that these are complaints in which the vulnerability or social deprivations of claimants have not necessarily been in issue. ${ }^{9}$

However, by comparison with modern constitutions, such as that of South Africa, where obligations have been graduated according to the severity of threats to rights, ${ }^{10}$ there are complex difficulties in the use of an old-fashioned instrument, predominantly expressed in terms of civil and political rights, to gain protection for human rights in the socioeconomic sphere. ${ }^{11}$ Moreover, lack of development of the normative content of the rights has been exacerbated by the Court's general failure to develop a coherent theory of positive obligations in the ECHR, or to pursue the logic of its own conclusions concerning the scope of positive obligations in welfare needs contexts. ${ }^{12}$ Furthermore, difficulties of standard setting have increased in a growing number of European states, each with very different constitutional arrangements, socio-political and economic histories, and ideological approaches to the role of the state in welfare protection. Thus, even commentators who recognise the long-term societal benefits of a more protective role for states than is now envisaged in post-welfare democracies are sceptical about the potential of the ECtHR case law to provide a coherent framework by which to pursue this goal. ${ }^{13}$

6 See L Clements and A Simmons, "European Court of Human Rights: sympathetic unease", in Langford, Social Rights Jurisprudence, n. 5 above; E Palmer, "Protecting socio-economic rights through the European Convention on Human Rights: trends and developments in the European Court of Human Rights" (2009) 2 Erasmus Law Review 397.

7 See Carson v UK (2009) 48 EHRR 41. The case concerned the general policy of the United Kingdom to pay index-linked pensions to residents while refusing to up-rate in the case of pensioners abroad unless they were resident in countries having reciprocal agreements with the UK.

8 Article 12 (4) states: "The Parties undertake . . . to take steps by the inclusion of bilateral agreements and multi-lateral agreements ... to ensure equal treatment of their own nationals and the nationals of other parties ... in respect of social security rights including the retention of benefits arising out of social security legislation whatever movements the persons undertake between the territories of the parties."

9 See Palmer, "Protecting socio-economic rights", n. 6 above, pp. 419-21.

10 Rights in the South African Constitution have been formulated in three different ways, each of which requires different responses from the courts. See, generally, D Brand, "Introduction to socio-economic rights in the South African Constitution" in D Brand and C Heyns (eds), Socio-economic Rights in South Africa (Pretoria: Pretoria University Law Press 2005), pp. 1-56. In respect of the second category of rights, which includes the majority of specific socio-economic rights (access to adequate housing, healthcare, food and water, and social security), the state is required to take reasonable legislative and other measures within its available resources to achieve the progressive realisation of the right. By contrast, the third category, which has been negatively formulated, prohibits the state from interfering with the enjoyment of other rights.

11 Generally, see E Palmer, Judicial Review, Socio-economic Rights and the Human Rights Act (Oxford: Hart 2007), pp. 49-103.

12 See A Mowbray, The Development of Positive Obligations under the European Convention on Human Rights by the European Court of Human Rights (Oxford: Hart 2004) for a comprehensive review of the development of positive obligations under the ECHR.

13 See O De Schutter, "The protection of social rights by the European Court of Human Rights" in J Vande Lannotte, J Sarkin, T De Pelsmaeker and P Van Der Auweraert (eds), Economic, Social and Cultural Rights: An appraisal of current international and European developments (Antwerp: Maklu 2002), pp. 207-39. See also, generally, Palmer, "Protecting socio-economic rights", n. 6 above. 
Two broadly different approaches to the development of positive socio-economic obligations can be found in the ECtHR's jurisprudence. In the first approach, the socioeconomic content of the rights, for example, to shelter or protection against destitution under Articles 3 or 8 ECHR, has been found to exist at the level of the Convention in order to give effective protection to the rights of the complainant in the circumstances of the case. ${ }^{14}$ In the second approach, the ECtHR has expanded the content of socio-economic rights that already exist in national legal systems by affording supplementary protection through explicit Convention rights, such as the right to a fair trial under Article 6 or the right to non-discrimination under Article 14.

The aim of this article is to evaluate these disparate approaches to the protection of socio-economic rights, in the context of a putative "right to shelter" in the ECHR, by focusing on the potential to gain access to housing or housing-related benefits through the incremental development of positive socio-economic obligations in the ECHR. It will also consider how these different strategic approaches have played out in the UK courts since the Human Rights Act 1998 (HRA). First, it argues that, despite the conceptual inadequacies of the positive-negative dichotomy of rights, its influence is still strongly reflected in ECtHR jurisprudence. Thus, it demonstrates that, despite the strategic progress in housing cases such as Connors $\mathrm{v} U K^{15}$ and McCann v UK, ${ }^{16}$ the ECtHR socio-economic jurisprudence reflects a strong bias towards claims involving negative interference with the enjoyment of an existing home. Second, it argues that in cases such as Tsfayo v UK ${ }^{17}$ (Article 6) and Stec v UK ${ }^{18}$ (Article 14), the ECtHR has pragmatically relied on an artificial extension of substantive rights to a fair trial and to a formal concept of equality that is inconsistent with the development of a principled jurisprudence of positive socio-economic obligations in the ECHR.

It is therefore suggested that, when assessing the ECtHR's contribution to the development of standards in the ECHR, an important distinction should be drawn between cases in which the content of the rights has been developed according to core principles and the values of equal respect for the dignity and autonomy of every human person that are immanent in all of the Convention rights, and cases in which a formal conception of equality has been used to create substantive rights that are akin to the notion of legally enforceable socio-economic entitlements for citizens in EU law. It is argued that only in the former cases can we see the promise of a jurisprudence of transformative positive obligations that fully respects the indivisibility of civil and political rights on the one hand and socio-economic rights on the other. ${ }^{19}$

\section{Beyond the negative-positive dichotomy of rights? Articles 3 and 8 ECHR}

Since Airey v Ireland, ${ }^{20}$ the ECtHR has developed positive obligations across the full range of Convention rights. However, it is well known that this phenomenon can most easily be demonstrated in relation to Article 8 ECHR. Not only has the ECtHR given expansive

14 Examples of fundamental socio-economic rights that have benefited from an autonomous protection by the ECtHR are found in the right not to be subjected to inhuman or degrading treatment (Article 3), the right to be exempt from servitude or forced labour (Article 4), the right to freedom of association (Article 11), and the right to respect for private and family life and home (Article 8).

15 (2005) 40 EHRR 9.

16 (2008) 47 EHRR 40.

17 (2009) 48 EHRR 18.

18 Stec v UK (2006) 43 EHRR 47.

19 See, generally, S Fredman, Human Rights Transformed: Positive rights and positive duties (Oxford: OUP 2008).

20 (1979-1980) 2 EHRR 305. 
interpretations to the substantive elements of Article 8 - private and family life, home and correspondence - the Strasbourg organs have also allowed the flexible concept of "respect" in Article 8(1) to support the development of a wide range of both positive and negative obligations in the ECHR. ${ }^{21}$ Moreover, although at first sight there is little to connect the negative formulation of Article 3 with the imposition of positive obligations, the ECtHR has concluded that state parties may be required to undertake a growing range of affirmative duties in order to be Article 3 compliant. ${ }^{22}$

However, it is also notable that in its dynamic development of Convention rights the ECtHR has continued to use the language of positive-negative duties, which is in contrast to the tripartite analysis that is now widely used to address the conceptual inadequacies of the negative-positive analysis of human rights. ${ }^{23}$ Nevertheless, it should also be emphasised that, when we examine the content of positive and negative duties that have been incrementally developed by the ECtHR to give practical effect to the Convention rights, we find a range of procedural and substantive obligations that, in practice, mirror those in Henry Shue's elaborate taxonomy of human rights obligations. Thus, affirmative duties across the range of ECHR rights can be described according to the threefold classification: a primary duty to avoid depriving a person of his or her basic rights (the duty to respect); a secondary duty to protect the right against interference from others (the duty to protect); and a duty to take procedural steps to promote (facilitate) rights.

Therefore, as Alistair Mowbray has shown, when we examine the identification by the ECtHR of positive obligations across the full range of ECHR rights, we find that the range and scope of duties is consistent with contemporary understandings that threats to all human rights require a host of protective and preventive measures that take into account the context in which the violation occurs, the seriousness of the threat, and the immediacy of the action required, including the spending of resources necessary to fulfil or facilitate the protection of the right. ${ }^{24}$ Thus, in the search for a more principled lens in Articles 3 and 8 ECHR, through which issues of state responsibility for extreme socio-economic deficits can be examined, Clements and Simmons have recently suggested that it is no longer helpful to follow the two broad categories "state action denied" and "state action demanded". Instead, they have suggested that, although still artificial, a better approach is to analyse state obligations according to context: to "what degree it can be said that the State [itself] is culpable and just how severe is the destitution in issue?" 25

Nevertheless, despite the unreliability of the negative-positive dichotomy, there have been concerns that a difference of treatment could be found, for example under Article 8 , depending on whether claims have been framed as allegations of negative or positive breaches of state duties. ${ }^{26}$ This is because, it is argued, in complaints framed as positive breaches of duty (failure to protect the right) it is all too easy for the question of breach to be conflated with the logically prior question of the scope of the duty encompassed by

21 For a comprehensive review of the development of positive obligations under the ECHR, see Mowbray, Development, n. 12 above.

22 Ibid. pp. 43-65.

23 Ibid. pp. 221-9.

24 Ibid.

25 See Clements and Simmons, "European Court of Human Rights", n. 6 above, p. 412. See also Palmer, "Protecting socio-economic rights", n. 6 above, pp. 53-65.

26 See C Warbrick, “The Structure of Article 8” (1998) EHRLR 1, pp. 32-44. 
Article 8(1). ${ }^{27}$ It has therefore been suggested that, where complaints are framed as positive breaches of duty, both parties may lose the benefit of the complex balancing exercise that has traditionally followed the preliminary inquiry and which has marked the evolution of the ECHR as a sophisticated mechanism of differential rights adjudication. ${ }^{28}$

However, in Powell and Rayner v UK, ${ }^{29}$ the ECtHR was clear that, whether a case is presented in terms of a positive state duty to take reasonable and appropriate measures to secure the applicant's rights under Article 8(1) or in terms of "an interference" by a public authority, the same methodological approach should be applied. Moreover, in response to similar concerns relating to allegations of breach of the positive aspects of Article 3 , in Rees $\mathrm{v}$ $U K, 30$ the ECtHR concluded that, despite the absence of an express requirement of proportionate interference, the defensive precepts in Article 8(2) are no less appropriate as yardsticks for determining the limits of state liability for positive breaches of duty under Article 3 ECHR. Nevertheless, in its analysis of the same question in Pretty $\mathrm{v} U K,{ }^{31}$ the Court significantly held that:

while states may be absolutely forbidden to inflict the proscribed treatment on individuals within their jurisdictions, the steps appropriate to discharge a positive obligation may be more judgemental, more prone to variation from state to state, more dependent on the opinion and beliefs of the people and less susceptible to any universal injunction. ${ }^{32}$

Thus, here we find a significant example of the ECtHR's reluctance to embrace a modern theory of human rights adjudication that fully acknowledges that, even though resources are implicated, issues of state responsibility should be determined not by the negative or positive designation of the right at issue, but rather by the immediacy and seriousness of the threat, the degree - if any - of state involvement and the extent to which resources are implicated in the satisfaction of the right.

Nevertheless, before concluding this section, it is also important to emphasise that, in its incremental development of affirmative duties, the ECtHR has not always been able to escape the logic of contemporary human rights theory: that positive obligations are an integral aspect of all human rights, rather than extraneous constructs superimposed on the existing catalogue of so-called negative rights. Nor has the ECtHR been immune from a growing trend in judicial review whereby international, constitutional and administrative courts are expected to shape our understanding of what is positively required of governments in protecting fundamental human rights, in addition to giving effective protection to the rights of the complainant in the circumstances of the case before it. ${ }^{33}$ Thus, although the Court is mindful of its institutional boundaries vis-à-vis national

27 See the remarks of Judge Wildhaber in Stjerna v Finland (1994) 24 EHRR 194, where it was recognised that it was difficult to address complaints founded on positive breaches of duty by means of the traditional methodological approach to determining whether there has been an intrusive violation of Article 8 .

28 (1987) 9 EHRR 56.

29 (1990) 12 EHRR 355. The applicants, who lived near Heathrow Airport, complained that excessive noise from the airport breached their right under Article 8 to respect for their private life and home. Therefore, as a preliminary issue, the government sought to question whether the complaint disclosed the necessary "interference by a public authority", because Heathrow Airport and the traffic using it were not owned or controlled by the government or its agents.

30 (1987) 9 EHRR 56. The applicant claimed that refusal by the UK government to allow her legally to alter her birth certificate so as to reflect her gender reassignment constituted a positive breach of her Article 8 right to respect for private life.

31 (2002) 35 EHRR 1.

32 Ibid. para. 15 (emphasis added).

33 See D Dyzenhaus, The Unity of Public Law (Oxford: Hart 2004), especially pp. 2-23. 
resource allocation policies, from time to time we see the tentative seeds of a principled jurisprudence of socio-economic obligations, especially under Articles 3 and 8 ECHR, that fully respects the indivisibility of civil and political and socio-economic rights.

Moreover, since the HRA 1998, these embryonic developments have lent themselves in UK courts to what has been hailed as the foundations of a transformative jurisprudence of positive socio-economic obligations in ECHR rights. ${ }^{34}$

\section{(A) Developing core obligations in Articles 3 and 8 ECHR}

Violations of Article 3 have increasingly been recognised by the ECtHR in complaints of state failure to provide conditions of human existence that satisfy the fundamental right of all humans to be treated with equal respect for dignity in relation to their basic needs, including the need for shelter. ${ }^{35}$ Moreover, although a positive duty to meet medical and other welfare needs of vulnerable individuals has most frequently been found in the context of prison or police custody, beyond those areas of dependency and state control it has also been recognised that failure to make provision for vulnerable claimants suffering from disabilities may, in humanitarian cases of sufficiently acute need, constitute infringements of Article 3. ${ }^{36}$ Moreover, two frequently cited cases have been widely viewed as authority for the proposition that state parties may be liable for violations of Article 3, whether committed by the state or its agents, in extreme circumstances, where there is a real risk that degradation and suffering are likely to be exacerbated by the failure of states to provide for the elementary health and welfare needs of individuals in their jurisdictions.

In the first of those cases, $D$ v United Kingdom, ${ }^{37}$ the applicant, a drug dealer from St Kitts who was suffering from AIDS, resisted a proposal by the UK government to return him to his country of origin, where treatment and ancillary support for AIDS sufferers was virtually non-existent. In his complaint to Strasbourg, he relied on a series of cases, starting with Soering v UK, 38 in which the ECtHR had demonstrated its willingness to extend the concept of a state's responsibility beyond its borders ${ }^{39}$ by interpreting Article 3 as including a prohibition on extradition or deportation in cases where there is a risk that an individual would face a sufficiently serious risk of ill-treatment if returned to another state. However, the test of severity in $D$ was set at a very high threshold, as recently confirmed by the ECtHR in $N v U K{ }^{40}$ It was accepted by the ECtHR in $N$ that, in deciding in favour of the applicant in $D$, the ECtHR had predominantly been influenced by such factors as the

34 S Fredman, "Human rights transformed: positive duties and positive rights" (2006) Public Law 498.

35 See, for example, Moldovan v Romania (No 2) (2007) 44 EHRR 16, concerning the Haderini pogrom which had been carried out with police complicity. The applicants' homes had been destroyed, as a result of which they lived in appalling conditions for 10 years, suffering very detrimental effects on their health and well-being. In conjunction with the racial discrimination they suffered, this constituted an interference with the applicants' human dignity and amounted to degrading treatment and a breach of Article 3.

36 See Price v UK (2002) 34 EHRR 53. See, generally, Palmer, "Protecting socio-economic rights", n. 6 above, pp. 410-12.

37 (1997) 24 EHRR 423.

38 (1989) 11 EHRR 439. In a series of cases starting with Soering v UK (1989) 11 EHRR 439, the ECtHR has interpreted Article 3 as including an absolute prohibition on extradition or expulsion where there is a sufficient risk that the complainant will face serious ill-treatment if returned to another state, thereby demonstrating the willingness of the ECtHR to extend the concept of state responsibility beyond a state's own borders.

39 See also Chabal v UK (1997) 23 EHRR 413; Vilvarajah v UK (1991) 14 EHRR 248; Jabari v Turkey App. No 40035/98, 11 July 2000.

40 Nv UK (2008) 47 EHRR 39; this applies beyond cases of AIDS to physical and mental illness generally (see para. 47). 
imminence of his death, the lack of sanitation in the receiving hospital in St Kitts, and the fact that there might not even have been a bed for him there.

In the second case, O'Rourke $\mathrm{v} U K,{ }^{41}$ the applicant was a vulnerable individual who on coming out of prison was provided with temporary accommodation pending a local authority decision as to whether he was eligible for housing as a homeless person. Following his eviction by the authority from temporary accommodation, he lived rough on the streets for 14 months, eventually complaining to Strasbourg that his eviction and the subsequent failure to provide him with accommodation constituted violations of Articles 3 and 8 ECHR. However, in his case, the Court did not consider the suffering that followed his eviction to have reached the requisite level of severity to engage Article 3. Moreover, since he was judged largely to be the author of his own misfortune (having failed to visit a night shelter and refused to accept temporary accommodation), there would have been no infringement of Article 3 even if his condition had reached the requisite level of severity. Significantly, however, the Court accepted that, although failure to provide shelter could not of itself amount to degrading and inhuman treatment, a positive obligation to make social provisions of the kind required by the applicant could arise in a case of sufficiently acute individual need. Further, it was emphasised by the Court that, as in the case of $D,{ }^{42}$ compliance with the negative duty in Article 3 could give rise to positive undertakings of this kind, in cases where a course of conduct pursued by the state (in these cases, deportation or eviction) is likely to result in inhuman or degrading consequences for the individual concerned. ${ }^{43}$

Nevertheless, although in isolation these cases have seldom been used successfully before the ECtHR to gain access to socio-economic provisions (within or beyond national borders), in the landmark House of Lords decision in $\mathrm{R}$ (Limbuela) $\mathrm{v}$ Secretary of State for the Home Department, ${ }^{44}$ they were absorbed as an integral part of the transformative human rights framework of ECHR positive socio-economic duties in Article 3. ${ }^{45}$

In Limbuela, the House of Lords had been asked to consider the circumstances in which the state's obligations (primarily under Article 3 ECHR) should extend to providing accommodation and basic necessities for destitute asylum seekers who were living without day-to-day certainty of food or shelter. However, the speeches of their Lordships went much further than that specific context. Thus, not only was it suggested that it is a basic value of the unwritten UK constitution that the state will always be responsible for preventing destitution arising as a result of a statutory regime of the kind imposed on the claimants that has removed all reliable and predictable forms of social support while at the same time preventing those whom they have made destitute from working. ${ }^{46}$ The speeches of their Lordships may also be viewed as articulating a more general and far-reaching proposition, namely that the state can be held responsible for meeting the basic needs of everyone in the jurisdiction wherever existing legal structures have been implicated in their denial. Indeed, the case has been widely applauded as coming close to suggesting a general principle that whenever individuals are reduced to abject poverty as a result of their

41 App. No 39022/97, admissibility decision, 26 June 2001.

42 (1997) 24 EHRR 423.

43 See also $N_{v}$ UK (2008) 47 EHRR 39.

44 [2005] UKHL 66, [2009] 1 AC 396.

45 In Limbuela, the House of Lords concluded that state responsibility is engaged where positive state action drives individuals into inhuman and degrading living conditions. For a full discussion of the case, see Palmer, "Protecting socio-economic rights", n. 6 above, pp. 265-70, an analysis cited with approval by the ECtHR in Nv UK (2008) 47 EHRR 39.

46 Palmer, "Protecting socio-economic rights", n. 6 above, pp. 265-70. 
inability to work, through old age or mental or physical infirmity, the state has a responsibility to ensure that their elementary needs are met through alternative appropriately tailored structures. ${ }^{47}$

Turning then to Article 8, we find that, as under Article 3, state parties may be required to protect individuals in respect of a broader bundle of social needs than at first sight presupposed by the constituent elements of Article 8: in the case of vulnerable individuals with disabilities, states may be required to take positive steps to provide them with an environment that will facilitate their enjoyment of autonomy and a more independent life in the wider community. ${ }^{48}$

The Court first considered the extent to which Article 8 gives rise to positive state obligations to make wider social provision for vulnerable individuals in Botta v Italy. ${ }^{49}$ This was a case in which the applicant complained of "impairment of his private life and the development of his personality" resulting from the Italian government's failure to take appropriate measures to remedy the omissions of the private bathing establishments in the town where he was taking a holiday. The essence of his complaint was that his Article 8 rights had been infringed because of his inability to enjoy a normal social life, "which would enable him to participate in the life of the community, by the exercise of his essential nonpecuniary personal rights". 50

It was recognised in Botta that the duty to protect physical and emotional integrity could arise even where there had been no direct interference by the state, ${ }^{51}$ although the Court refused to find that there had been a violation of Article 8 in a case where the right asserted by the applicant (to gain access to beach and sea at a place distant from his normal place of residence) "concerned interpersonal relations of such broad and indeterminate scope that there could be no conceivable direct link between the measures the state was urged to take and the applicant's private life". ${ }^{2}$ At the same time, however, the ECtHR recognised that, in principle, Article 8 could give rise to precisely the type of affirmative duties for which the applicant had argued in cases where it was possible to establish "a direct and immediate link between the measures sought by an applicant and the latter's private and/or family life". 53

Nevertheless, the ECtHR in Botta drew attention to the concurring opinion of the minority in the European Commission, in so far as the Commission had recognised that the precise aim and nature of the measures to be undertaken for people with disabilities would vary from place to place and that this was an area where a wide discretion would always be left to national governments. Moreover, in seeking further to limit the implications of its own jurisprudence, the Court recalled the more cautious opinion of the Commission's majority, namely that, in light of the resources necessary to satisfy such a claim, "the social nature" of the rights at issue rendered them more suitable for protection under the flexible machinery of the ESC. 54

47 C O'Cinneide, "A modest proposal: destitution, state responsibility and the European Convention on Human Rights" (2008) EHRLR 583.

48 See Clements and Simmons, "European Court of Human Rights", n. 6 above, p. 422.

49 (1998) 26 EHRR 241.

50 Ibid. para. 27.

51 Ibid. paras 32-3.

52 Ibid. para. 35 .

53 Ibid. para. 34.

54 Botta v Italy (1998) 26 EHRR 241, proceedings before the Commission, 246-55. For the concurring minority opinion on the application of the margin of appreciation of Judges Liddy, Tune, Pellonpää, Bratza, Sváby, Perenic and Schermers, see 251-2. 
Since Botta, there have been few successes before the ECtHR in claims for social care by disabled people seeking to enjoy autonomy and independence in the wider community. ${ }^{55}$ However, by contrast, in the UK, since the closely reasoned judgment by Sullivan J in Bernard v Enfield LBC, 56 the principles enunciated by the ECtHR in Botta have provided the bedrock for an important jurisprudence of positive public authority duties concerning social support for vulnerable groups, such as children and frail, elderly and disabled people. Thus, although agreeing in Bernard that the main thrust of Article 8 is to prevent arbitrary interference by public authorities with an individual's private and family life, Sullivan J was not prepared to overlook the relevance of developments in ECtHR jurisprudence in which, in the wake of Botta, respect for individuals' psychological and physical integrity had been recognised as giving rise to positive obligations of the kind at issue in Bernard. ${ }^{57}$

However, by contrast, when we turn to examine Article 8 disputes that are more directly concerned with the "home" component of Article 8 in the concrete physical sense, we find that the ECtHR has shied away from a principled jurisprudence of positive obligations of the kind explored in Botta. Instead, recent Article 8 cases claiming home protection in the concrete physical sense continue to reflect a bias towards claims involving negative interference with the enjoyment of an existing home.

\section{(B) BEYOND ARBITRARY INTERFERENCE: THE RIGHT TO A HOME?}

The core idea of respect for the home in Article 8 ECHR is said to be one of sanctuary against intrusion by public authorities, that is an essentially negative obligation. ${ }^{58}$ However, there is a wide penumbra of positive connotations in the idea of respect for "home, family and private life". ${ }^{59}$ Further, it is clear that the state will facilitate the right to live in one's existing home rather than merely protect it against interference as an existing property

55 See Zebnalova and Zebnal v Czech Republic App. No 38621/97, admissibility decision, 14 May 2002. The applicants were partners, one of whom was disabled. They complained that, in contrast to the complaint by Botta, they were unable to access a number of public buildings such as the post office and swimming pool in their home town. The ECtHR doubted that they needed access to the buildings listed on a daily basis, but also denied that there was a direct and immediate link between the measures sought and the applicants' private lives. See also Sentges v The Netherlands App. No 27677/02, admissibility decision, 8 July 2003.

56 [2002] EWHC (Admin) 2282. See also Anufrejiva v Soutbwark London Borough Council [2003] EWCA Civ 1406, where Lord Woolf endorsed the counterintuitive conclusion accepted by Sullivan J in Bernard that treatment that does not reach the severity of Article 3 degradation may nonetheless constitute a breach of the private life aspects of Article 8 when adverse effects on an individual's moral and physical integrity are sufficiently grave.

57 The first applicant in Bernard [2002] EWHC (Admin) 2282, who had been severely disabled following a stroke, suffered from a range of infirmities that left her confined to a wheelchair and wholly dependent on others for her personal care, hygiene and feeding. Sullivan J concluded that the local authority was under an obligation not merely to refrain from unwarranted interference in the claimants' family life, but also to take positive steps, including providing suitably adapted accommodation, to enable the claimants and their children to lead as normal a family life as possible, bearing in mind the first applicant's severe disabilities.

58 See D Harris, M O'Boyle, E Bates and C Buckley, Law of the European Convention on Human Rights 2nd edn (Oxford: OUP 2009), p. 376. In complaints against Turkey concerning the burning of houses by security forces, the ECtHR found that the destruction of the applicants' homes and properties constituted particularly grave and unjustified interferences with the their right to respect for their home, private and family life. See also Selcuck and Asker v Turkey (1996) 26 EHRR 477. The positive state obligations under Article 8 may also relate to the right to "adequate housing", although it appears from the case law that these obligations rest more clearly on the "private and family life" components of Article 8 than on the specific reference to "respect for home".

59 The essential ingredient of family life is the right to live together so that family relationships may develop normally: see Marckx v Belgium (1979) 2 EHRR 330. Powell and Rayner v UK (1990) 12 EHRR 355 concerned a duty to protect a person's home and family life from the negative interference of environmental pollution. 
right. ${ }^{60}$ Nevertheless, although there are positive state obligations to protect against home deprivation and its consequences in many contexts, ${ }^{61}$ the ECtHR has attempted to set justiciable boundaries around the growing social problem of homelessness in Europe by using the well-known mantra that "there is no right to a home". Thus, in Chapman v UK, ${ }^{62}$ the ECtHR familiarly stated that:

while it is clearly desirable that every human being have a place where he or she can live in dignity and which he or she can call home, there are unfortunately in the Contracting States many persons who have no home. Whether the state provides funds to enable everyone to have a home is a matter for political not judicial decision. ${ }^{6}$

Nevertheless, it is well known that the defensive statement that there is no right to a home in Chapman sits uneasily with developments in Botta and with Marzariv Italy, ${ }^{64}$ the first case in which the ECtHR clearly stated that, although not creating a right to a home per se, the positive duty in Article 8 to respect private family life did not absolve the government of all responsibilities in respect of housing needs. In Marzari, the Court recognised that:

Although Article 8 does not guarantee the right to have one's housing problems solved by the authorities, a refusal of the authorities to provide assistance in this respect to an individual suffering from a severe disease might in certain circumstances raise an issue under Article 8. ${ }^{65}$

Further, in determining whether the interference complained of was necessary in a democratic society, the Court stressed that the applicant's medical condition was particularly relevant to his need for accommodation, as the applicant had to be hospitalised as a consequence of his living in a camper van after his eviction. Moreover, although the ECtHR found no violation of Article 8 in Marzari, when performing the exercise of appreciation, as in Botta, it took the important step of recognising that, in the case of a person suffering from a disability, the burden of justifying the refusal of accommodation under Article 8(2) might be greater than in other cases.

However, in Chapman v UK, ${ }^{66}$ one of several UK Gypsy cases, which concerned an interference with the applicant's Article 8 rights caused by a failure to grant her planning permission to live in a caravan on her land, ${ }^{67}$ eight members of the ECtHR recalled in a strong dissenting opinion that, although the essential object of Article 8 is to protect the individual against arbitrary action by public authorities, there may in addition be positive obligations inherent in an effective "respect for private and family life and home". In

60 See Howard v UK App. No 10825/84, 52 DR 198 (1987). See also Cyprus v Turkey App. Nos 6780/74 and $6950 / 75$, where the Commission dealt with the denial to Greek Cypriots of access to their homes in the north of Cyprus under Article 8 and Article 1 of Protocol 1.

61 See e.g. Moldovan v Romania (No 1) (2007) 44 EHRR 16. It has been suggested that "this is best described as a remedial right - to compensate for deprivation of housing". See Clements and Simmons, "European Court of Human Rights", n. 6 above, p. 413.

62 (2001) 33 EHRR 18.

63 Ibid. para. 99G.

64 (2000) 30 EHRR CD218.

65 Ibid.

66 (2001) 33 EHRR 18.

67 In the UK in a series of cases, starting with Buckley v UK (1996) 23 EHRR 101, it had been alleged that land development controls had unfairly discriminated against gypsies, with the result that almost 30 per cent of them were technically homeless and that controls that made it particularly difficult to obtain permission for the stationing of a caravan constituted a form of indirect discrimination. Second, complainants had argued that the legitimate state action has had a disproportionate (if unintended) socio-economic effect and that either the scheme should be amended to make it possible for them to find their own accommodation or the state should take responsibility for its provision. 
addition, they noted that positive duties to respect a person's home might arise even in cases where there has been no state interference of the kind identified in Chapman. Thus, in considering whether the applicant's eviction served a "pressing social need", referring to the judgments in Marzari ${ }^{68}$ and Botta, ${ }^{69}$ the minority recalled that "where there is a direct and immediate link between the measures sought by an applicant and the latter's private life, positive obligations may be imposed on states".

Since Chapman, the ECtHR has demonstrated that, in sensitive "housing" cases concerning the legitimacy of interference (rather than the state's failure to provide housing), the Strasbourg Court will not routinely fall back on the wide margin of appreciation associated with domestic resource allocation issues or sensitive issues of general housing policy. Thus, in Connors v $U K,{ }^{70}$ which concerned the legality of a gypsy's forced eviction from a local authority caravan site on the ground of the alleged misbehaviour of his extended family, ${ }^{71}$ the ECtHR modified its position in Chapman. It was said in Connors that weighty reasons of public interest would be required to justify the very severe interference with the applicant's Article 8 rights, namely eviction and homelessness resulting in very detrimental effects on his and his family's health and education, circumstances that had not existed in Chapman. Accordingly, the ECtHR stated that "a margin of appreciation must inevitably be left to the national authorities", which "by reason of their direct and continuous contact with the vital forces of their countries, are, in principle, better placed than an international court to evaluate local needs and conditions". ${ }^{72}$ However, on the issue of proportionality, the Court stated that, although in general it is for the national authorities to make the initial assessment of necessity, "the final evaluation as to whether the reasons cited for the interference are relevant and sufficient remains subject to review by the Court for conformity with the requirements of the Convention". 73 The margin will therefore vary "according to the nature of the Convention right in issue, its importance for the individual and the nature of the activities restricted, as well as the aim pursued by the restrictions". ${ }^{74}$ It will "tend to be narrower where the right at stake is crucial to the individual's effective enjoyment of intimate or key rights". ${ }^{75}$

By contrast, it was said that a wide margin of appreciation is more likely to be applied in contexts such as planning, in so far as "the exercise of discretion involving a multitude of local factors is inherent in the choice and implementation of planning policies". ${ }^{76}$ Thus, "in spheres such as housing, which play a central role in the welfare and economic policies of modern societies" (particularly in cases where Article 1 of Protocol 1 is in play), the legislature's judgment as to what is in the general interest will generally be respected, "unless that judgment is manifestly without reasonable foundation". ${ }^{77}$ It is also possible to

68 (2000) 30 EHRR CD218.

69 (1998) 26 EHRR 241.

70 (2005) 40 EHRR 9.

71 In Connors (2005) 40 EHRR 9, the applicant and his family had lived on a local authority caravan site for 13 years. Following eviction, the family was forced to move on continuously and the stress led to the breakdown of the applicant's marriage. In finding a violation, the ECtHR emphasised the lack of procedural protection for gypsies in comparison to the local authority reviews of anti-social behaviour on local authority housing estates. Although the applicant denied the allegations, he had no opportunity to challenge them in court.

72 (2005) 40 EHRR 9.

73 Ibid. para. 81.

74 Gillow v UK (1986) 11 EHRR 335, para. 55.

75 Connors v UK (2005) 40 EHRR 9, para. 82.

76 Ibid.

77 Ibid. 
distinguish cases such as Mellacher v Austria (founded on Article 1 of Protocol 1) from disputes founded on Article 8, which was said uniquely to "concern rights of central importance to the individual's identity, self-determination, physical and moral integrity, maintenance of relationships with others and a settled and secure place in the community". 78

Moreover, the ECtHR has emphasised that, even where general social and economic policy considerations arise under Article 8, "the scope of the margin of appreciation depends on the context of the case, with particular significance attaching to the extent of the intrusion into the personal sphere of the applicant". In Connors, the "eviction of the applicant and his family ... was not attended by the requisite procedural safeguards, namely the requirement to establish proper justification for the serious interference with his rights". It could not be regarded as justified by a pressing social need or proportionate to the legitimate aim being pursued. Accordingly, there had been a violation of Article 8 .

Nevertheless, in the United Kingdom there is a well-known tension between the use of eviction as a legitimate tool for the management of depleted social housing stock and the effective protection of the right to respect for the home in Article 8 ECHR. This tension was not directly addressed in Connors. In the later case of McCann v UK, ${ }^{79}$ the ECtHR was therefore asked to consider whether the applicant's eviction from his home (which served a legitimate aim and had been conducted in accordance with relevant legal procedures) constituted an interference with his right to respect for his home. ${ }^{80}$ As in Connors, the central question was whether, in the applicant's case, the interference was proportionate and necessary in a democratic society. ${ }^{81}$ Significantly, the ECtHR held that it was not, suggesting that domestic law must always permit the proportionality of removing a person from his or her home to be assessed by an independent tribunal (which is currently not the case in the $\mathrm{UK}$ ) if it is to comply with Article 8. Notably, however, in the later case of Doherty v Birmingham City Council, 82 the House of Lords decided to depart from the ECtHR judgment in McCann, arguing that it was based on a fundamental failure to understand the complexities of English housing law and therefore did not have to be followed in the domestic courts.

In the foregoing analysis of Article 8 case law, it has been argued that, despite the potential for the positive obligation in Article 8 to protect vulnerable individuals in respect of a bundle of needs, including the need for shelter, successful challenges before the ECtHR have continued to reflect a bias towards claims involving negative interference with the enjoyment of an existing home. Although regrettable, this is not surprising. Here, perhaps more than in any other area of social needs, we see the limitations of on an oldfashioned instrument, primarily directed at preventing negative state interference, in this case with individuals' substantive possessory rights under Article 1 of Protocol 1, when vulnerable individuals in need are seeking to gain access to adequate housing.

78 The ECtHR cited Pretty v UK (2002) 35 EHRR 1 and Goodwin v UK (1996) 22 EHRR 123.

79 (2008) 47 EHRR 40.

$80 \mathrm{Mr}$ McCann and his wife were joint secure council tenants. Mrs McCann was re-housed by the council on the ground of domestic violence. At the council's instigation, she signed a notice to quit (without realising that this would bring the joint tenancy to an end). Mr McCann sought to transfer the tenancy to his own name but was duly evicted.

81 The ECtHR refused to accept the UK government's contention that the Connors decision (2005) 40 EHRR 9 was to be confined only to cases involving gypsies or where applicants sought to challenge the law itself rather than its application in their particular case.

82 [2008] UKHL 57, [2009] 1 AC 367. 
Reflecting further on the significant problem of the indeterminacy of content of socioeconomic rights in the ECHR, in relation to the "right to be adequately housed" it is worth remembering that even in the South African Constitution, which affords express protection to civil, political and socio-economic rights, housing obligations requiring "fulfilment" by the state have been carefully circumscribed. Thus, s. 26 of the constitution, which imposes a positive duty on the state and other relevant role players to "desist from preventing or impairing the positive right of access to housing", deals only with court procedures relating to arbitrary evictions rather than those that are carried out within the law. ${ }^{83}$ In respect of the majority of specific socio-economic rights (access to adequate housing, healthcare, food and water, and social security), the state is required to take reasonable legislative and other measures within its available resources to achieve the progressive realisation of the right.

\section{Articles 6 and 14: towards the fair distribution of socio-economic entitlements in member states?}

In the foregoing review of cases under Articles 3 and 8 ECHR, we have seen the potential for progress through the development of core values and principles that give rise to opentextured positive obligations of the kind enshrined in Article 11 ICESCR (to recognise "the right of everyone to an adequate standard of living for himself and his family") or in Article $30 \mathrm{ESC}$ (the right to protection against poverty and social exclusion). ${ }^{84} \mathrm{By}$ contrast, the fair trial right in Article 6 ECHR and the non-discrimination provision in Article 14 ECHR, coupled with substantive benefits, such as property and education (covered in Protocol 1 to the ECHR), have been used by the ECtHR to protect substantive socio-economic entitlements of the kind protected in Article 9 ICESCR or Article 12 ESC. 85 Thus, in the following review of cases, this article's focus turns from concern with equal protection of socially disadvantaged individuals in accordance with the core value of equality that infuses the entire Convention to more formal conceptions of equality in relation to the distribution of public goods.

\section{(A) ARTICle 6 ECHR: ACCESS TO ADMINISTRATIVE JUSTICE IN SOCIAL SECURITY CLAIMS}

It has already been noted how the right to free legal assistance as a "social" dimension of the right to a fair trial was first emphasised by the ECtHR in Airey. ${ }^{86}$ Since then, the ECtHR has continued to recognise that the specific guarantees protected by Article 6 , such as the right to an oral hearing and to legal aid, can be crucial in assisting disadvantaged individuals to gain access to assistance that might otherwise be denied in criminal proceedings. ${ }^{87}$

However, Article 6 does not apply to all proceedings - only to those concerning the determination of civil rights and obligations or a criminal charge - and in interpreting these concepts the ECtHR has given them "autonomous meanings" that in many cases depart from their meanings in domestic law. Thus, gradually, the scope of the concept of civil rights and obligations has been widened to encompass a right of access to courts or

83 See n. 10 above.

84 See n. 8 above.

85 Article 12 (4) states: "The Parties undertake . . . to take steps by the inclusion of bilateral agreements and multi-lateral agreements. . . . to ensure equal treatment of their own nationals and the nationals of other parties ... in respect of social security rights including the retention of benefits arising out of social security legislation whatever movements the persons undertake between the territories of the parties."

86 (1979-1980) 2 EHRR 305.

87 Article 6(3) (c) guarantees the right of a person charged with a criminal offence to have access to practical and effective legal assistance. See Lundevall v Sweden App. No 38629/97, 12 November 2002; Sallomonsson v Sweden App. No 38978/97, 12 November 2002; Miller v Sweden App. No 55853/00, 8 February 2005. 
tribunals in public law disputes over most discretionary socio-economic benefits. For example, early in the Court's jurisprudence, even though the right to health insurance benefits under social security schemes was treated as a public law right in the Netherlands, in Feldbrugge $\mathrm{v}$ The Netherlands, ${ }^{88}$ it was held to constitute a civil right within the autonomous meaning of Article 6(1). ${ }^{89}$

Moreover, the ECtHR has held that the formal principle of equality of treatment dictates that Article 6 should apply even in cases where a socio-economic benefit is derived from a discretionary, non-contributory form of public assistance granted unilaterally by the state $^{90}$ and where the cost is fully borne by the public purse without any link to a private contract of employment. ${ }^{91}$ Thus, in Salesi v Italy, ${ }^{92}$ the definition of a civil right was said to cover social security or welfare benefits regarded as "sufficiently well defined to be analogous to rights in private law" and of "economic significance to the claimant". 93 Since the features of private law claims predominated, the right to social security benefits was a civil right within the meaning of Article $6 .{ }^{94}$

But the Court's "dynamic" approach to remedying the Convention's failure to include rights of due process in public law disputes has been problematic. In many jurisdictions, including the UK, the requirement of a "full hearing" under Article 6 disturbs existing models of administrative dispute resolution and the public-private jurisdictional divide. Thus, seeking a flexible accommodation in the case of Bryan $\mathrm{v} U K,{ }^{95}$ the ECtHR concluded that "full jurisdiction" in public law disputes means jurisdiction to deal with the case as the nature of the decision requires, in accordance with the dictates of "democratic accountability, efficient administration and the sovereignty of Parliament". 96 Problematically, there is no clear guidance as to how the criteria enunciated in Bryan are to be applied in national jurisdictions. In the UK, there has been intense litigation concerning the limits of the right to a full hearing in administrative disputes over discretionary socio-economic entitlements relating to housing. ${ }^{97}$ This culminated in the recent case of Tsfayo $\mathrm{v} U K{ }^{98}$

Tsfayo concerned the application of Article 6 ECHR to a decision by a housing benefits review tribunal to refuse payment of housing benefit to a non-English-speaking asylum seeker because she had failed to show "good cause" why she had not submitted her renewal claim on time. On her complaint to Strasbourg, the ECtHR decided that the tribunal had been in breach of Article 6, irrespective of whether the claimant had had access to a

88 (1986) 8 EHRR 245.

89 See also König v Germany (1978) 2 EHRR 170. The ECtHR concluded that the right to practise medicine in West Germany was a civil one. The fact that the medical profession did not provide a "public service" in Germany was taken into account in reaching this conclusion.

90 Salesi v Italy (1993) 26 EHRR 187.

91 Where a pension is linked to employment, even to employment in the civil service, the ECtHR has held $a$ fortiori that Article 6 will be engaged. See Lombardo v Italy (1992) 21 EHRR 18, paras 14-17; McGinley and Egan v UK (1999) 27 EHRR 1, para. 84.

92 (1996) 21 EHRR 342

93 Ringeisen v Austria (No 1) (1971) 1 EHRR 455.

94 This was despite a powerful dissent from seven members of the Court, who said that the distinctions between public and private law were being eroded in a way that would cause great uncertainty.

95 (1996) 21 EHRR 342

96 Per Lord Hoffman in Begum v London Borough of Tower Hamlets [2003] UKHL 5, [2003] 2 AC 430, paras 35 and 43.

97 In Runa Begum, the House of Lords held that administrative burdens and other societal costs associated with constitutional entitlements to a full evidentiary hearing should legitimate a more limited form of adjudication in disputed claims to discretionary welfare benefits. 
traditional judicial review hearing on appeal. In her case, the ECtHR insisted that intricately linked to the councillors' manifest lack of independence was the "limited control" that could be exercised by the reviewing court. ${ }^{99}$ It did not have jurisdiction to rehear the evidence or to substitute its own views as to the applicant's credibility. Nor, indeed, did it have the power to order the decision to be taken by a different body. This meant that:

there was never a possibility that the central issue of the applicant's credibility would be determined by a tribunal that was independent of one of the parties to the dispute. Accordingly, there had been a violation of Article 6(1). ${ }^{100}$

In seeking to give effect to rights that were "real and not illusory", in the circumstances of the case, the ECtHR concluded that there had been an infringement of the claimant's right to a fair and impartial hearing. However, if the ECtHR's approach to the interpretation of Article 6 in that case were given general application in the UK, it would mean that disputes of fact could no longer be determined internally at first instance: the existing supervisory administrative structure is inadequate to guarantee an impartial determination of all aspects of the dispute. The decision therefore threatened to disrupt established internal administrative procedures and court hearings for the allocation of welfare entitlements that have long been regarded by courts in the UK as uniformly hedged around by sufficient safeguards to satisfy the guarantees in Article 6.

Therefore, in the recent case of Ali v Birmingam City Council, 101 the Supreme Court sought to row back from the pragmatic, albeit generous, interpretation of "civil rights" in Runa Begum, ${ }^{102}$ where, although rejecting her claim, the House of Lords had decided (in order to avoid over-judicialisation of the issue) that a review of homelessness appeals by a local authority housing officer under s. 193 (5) of the Housing Act 1996 constituted a determination of the applicant's "civil rights" within the meaning of Article 6(1) of the ECHR. Thus, in Ali, having reviewed a small number of ECtHR authorities since Runa Begum, including Stec v UK, ${ }^{103}$ the Supreme Court unanimously concluded that:

cases where the award of services or benefits in kind is not an individual right of which the applicant can consider himself the holder, but is dependent on a series of evaluative judgments by the provider as to whether the statutory criteria are satisfied and how the need for it ought to be met ... do not give rise to "civil rights" within the autonomous meaning that is given to that expression for the purposes of . . A Article 6(1). ${ }^{104}$

The right to administrative due process has long been regarded as one of the most important avenues for the protection of socio-economic rights of the vulnerable and

99 Under the system as it applied, the hearing had taken place before a tribunal that consisted of members of the same local authority that would be required to pay 50 per cent of the benefit awarded in the event of a finding in the applicant's favour.

100 (2009) 48 EHRR 18, paras 46-9.

101 [2010] UKSC 8, [2010] 2 WLR 471.

102 Begum v London Borough of Tower Hamlets [2003] UKHL 5, [2003] 2 AC 430.

103 (2006) 43 EHRR 47.

104 Per Lord Hope, para. 49. Lord Collins preferred to place "less emphasis on the evaluative nature of the exercise under section 193 and greater emphasis on the nature of the applicant's rights . . and in particular on the absence of what the Strasbourg Court has characterised as an important and perhaps necessary feature, namely an individual economic right in the applicant", para. 58. See also the Supreme Court's decision in $\mathrm{R}(A)$ v Croydon London Borough Council [2009] UKSC 8, [2009] 1 WLR 2557, where the court concluded that a local authority decision as to whether or not to provide accommodation for children in need under s. 20 of the Children Act 1989 was a determination of a civil right within the meaning of Article 6(1). 
marginalised. ${ }^{105}$ However, despite the need for appropriate protection of rising numbers of destitute and socially disadvantaged claimants seeking access to a largely depleted stock of public housing, we see very clearly the disadvantages of a jurisprudence that has not developed according to abstract principles and standards, but, in the case of Article 6, in accordance with a formal notion of equality and, by analogy, with private law dispute resolution where very different principles, procedures and standards apply.

\section{(B) ARTICLE 14: tHE ECTHR APPROACH TO THE FAIR DISTRIBUTION OF SOCIAL SECURITY BENEFITS}

It is well known that, in contrast to more sweeping provisions in many written constitutions and human rights instruments (most notably the very broad formulation of the Fourteenth Amendment to the US Constitution), ${ }^{106}$ Article 14 has been restricted in two ways. First, the substantive arena in which discrimination is forbidden has been restricted to the "enjoyment of the rights and freedoms set forth in [the] Convention". Second, the grounds upon which discrimination is forbidden have been restricted to "any ground such as [the specified grounds] or other status". ${ }^{107}$ Moreover, although those limitations have to some extent been addressed by the adoption of Protocol 12, many member states, including the UK, have failed to ratify the protocol. ${ }^{108}$ Thus, Article 14 continues to impose a duty on the state and public authorities acting within the scope of Convention rights not to discriminate on the listed grounds, or on the grounds of "other status", unless the discrimination can be justified.

Nevertheless, the ECtHR has attempted to overcome those restrictions in a variety of ways: by at times avoiding the "ambit" discussion altogether (by treating some discriminatory acts as violations of Article $3^{109}$ or Article 8 ECHR) ${ }^{110}$ while, in other cases, bringing allegations of discriminatory treatment (for example, in the distribution of social security benefits) within the ambit of Article 14, although, notably, the ECtHR seldom uses Articles 8 or 3 in conjunction with Article 14.

Thus, in Gaygusus v Austria, ${ }^{111}$ the ECtHR confirmed that, by analogy with the proprietary right of a contributor to a private pension fund, a claim to contributory benefits in the Austrian municipal system was a possession, thereby grounding the complaint within

105 The access to justice movement in the USA was spearheaded by M Cappelletti and had a bias towards collective group action. See M Cappelletti, Judicial Review in the Contemporary World (Indianapolis: Bobs-Merrill 1971).

106 Cf. also Article 26 of the International Covenant on Civil and Political Rights, which has a much stronger freestanding text than Article 14 ECHR.

107 Article 14 states: "The enjoyment of the rights and freedoms set forth in this Convention shall be secured without discrimination on any ground such as sex, race, colour, language, religion, political or other opinion, national or social origin, association with a national minority, property, birth or other status."

108 Cf. Article 1 of Protocol 12, which has been formulated by the Council of Europe to apply to "any right set forth by law", thereby purporting to extend its territory widely. As of July 2010, Protocol 12 had been ratified by just 17 states, although a further 17 had signed it.

109 Moldovan v Romania (No 2) (2007) 44 EHRR 16 (racial discrimination); Price v UK (2002) 34 EHRR 53 (disability discrimination).

110 Article 8 (the right to respect for private and family life) has been successfully invoked in a series of cases concerning discrimination against gay men and lesbians and persons who have had gender reassignment. See Christine Goodwin v UK (1987) 9 EHRR 56, para. 90.

111 In Gaygusuz v Austria (1996) 23 EHRR 365, a Turkish man who had worked in Austria for 10 years had been refused the social benefit of an advance on his pension in the form of emergency assistance on the grounds that it could only be claimed by Austrian citizens. This was discrimination under Article 14, read in conjunction with Article 1 of Protocol 1. 
Article 14 taken together with Article 1 of Protocol $1 .^{112}$ Moreover, relying on that approach in the case of Kona Poirrez. v France, ${ }^{113}$ the ECtHR decided that difference in treatment with respect to entitlements to social benefits between French nationals (or nationals of a country having signed a reciprocity agreement) and other foreign nationals was not based on any objective and reasonable justification. The Court therefore concluded that the government's refusal to allow the applicant, an Ivorian national, to claim disability benefits constituted a breach of Article 14 taken in conjunction with Article 1 of Protocol 1:114 "Very weighty reasons would have to be put forward before the Court could regard a difference of treatment based exclusively on the ground of nationality to be compatible with the Convention". 115

Although there are many jurisdictions, including a number of new accession countries, where, as in the $\mathrm{UK},{ }^{116}$ contributions to the social security fund are regarded as hardly distinguishable from general taxation, this difficulty has been surmounted in Strasbourg by means of a technical argument to the effect that, although a claim to a social security benefit is a possessory right falling within the ambit of Article 1 of Protocol 1, it differs from a purely private law right to the extent that it does not entitle the claimant to "anything in particular". ${ }^{117}$ Thus, the admissibility decision in Stec $\mathrm{v} U K,{ }^{118}$ in which the ECtHR extended the ambit of property rights to include any social security payment, was confirmed by the Grand Chamber in 2007, ${ }^{119}$ thereby deciding that, despite their non-contributory nature, such benefits are invariably governed by the non-discrimination principle. Accordingly, the ECtHR held by 16 votes to one that there had been no violation of Article 14 taken together with Article 1 of Protocol 1 in respect of the cessation of Reduced Earnings Allowance at different ages for men and women.

Until recently, Article 14 jurisprudence was overwhelmingly devoted to a formal equality model. Thus, although it has allowed for stricter standards of scrutiny in "suspect classes" of discrimination, such as sex and most recently race, ${ }^{120}$ the ECtHR has focused primarily on the extent to which there was a difference in treatment of analogously placed persons according to status and "situations" before seeking to determine whether the difference served a legitimate aim and was proportionate.

112 Article 1 of Protocol 1 provides: "Every natural or legal person is entitled to the peaceful enjoyment of his possessions. No one shall be deprived of his possessions except in the public interest and subject to the conditions provided for by law and by the general principles of international law."

113 (2005) 40 EHRR 34. para. 37.

114 The applicant was of Ivorian nationality but resident in Paris and adopted by a French national.

115 The ECtHR relied on Gaygusuz v Austria (1996) 23 EHRR 365 where, by contrast, the right to payments had been linked to the nature of the contributory system. But see the dissenting opinion of Judge Mularoni who, distinguishing Koua Poirrez from Gaygusuz, on grounds that it involved non-contributory benefits for disabled people, argued that, although there had been no violation of Article 14 taken in conjunction with Article 1 of Protocol 1, there had been a violation of Article 14 taken in conjunction with Article 8. See Koua Poirrez (2005) 40 EHRR 34, para. 46. See also Stec v UK (2006) 43 EHRR 47, para. 53: "If ... a Contracting State has in force legislation providing for the payment as of right of a welfare benefit - whether conditional or not on the prior payment of contributions - that legislation must be regarded as generating a proprietary interest falling within the ambit of Article 1 of Protocol No. 1 for persons satisfying its requirements."

116 See R (Carson) v Secretary of State for Work and Pensions [2005] UKHL 37, [2006] 1 AC 173, para. 12.

117 See Jankovic v Croatia (2000) 30 EHRR CD183.

118 Stec $\mathrm{v}$ UK (2006) 43 EHRR 47.

119 As noted by Judge Borrego Borrego in his concurring judgment, by widening the notion of possessions to include welfare benefits and by establishing a link between Article 14 and Article 1 of Protocol 1, the ECtHR has by implication secured "the entry into force of Protocol No. 12 in a very important sphere (social security benefits) in respect of a Contracting Party which had not even signed Protocol 12".

120 See e.g. Timishev v Russia (2005) 44 EHRR 76. 
However, a more nuanced approach has developed in social security case law, as demonstrated in the Court's recent decision in Carson v UK. ${ }^{121}$ That case concerned the general policy of the UK to pay index-linked pensions to residents while refusing to up-rate in the case of pensioners abroad. The ECtHR emphasised the importance of a wide margin of appreciation in cases involving social security systems (specifically pensions), referring also to the "very wide margin, which the state enjoys in matters of socio-economic policy". However, the ECtHR also stressed the importance of justification and did not suggest that the courts should abnegate their reviewing role - where the state's policy is not rational a national court may say so. ${ }^{122}$ Moreover, the ECtHR also spelled out in Stec that a difference of treatment that is prima facie discrimination under Article 14 can be justified in cases where it is intended to correct "factual inequalities". 123

In contrast to this small progress, however, we have seen that historic limitations in the drafting of Articles 6 and 14 have hampered the Convention's evolution as an instrument for the principled resolution of disputes concerning the fair distribution of socio-economic entitlements in member states. In the case of Article 6, emphasis on a formal conception of equality, directed at the assimilation of public and private law claims, has left little room for the development of a Convention jurisprudence focused on what due process may require when discretionary socio-entitlements are withheld from vulnerable and dependent individuals in need. Moreover, as we have seen in the context of Article 14, a formal conception of equality has similarly encouraged the ECtHR to focus more closely on the artificial extension of the range of substantive socio-economic rights covered by the Convention than on efforts to address issues of systemic socio-economic deprivation more holistically through the development of a principled substantive model of equality in the Convention jurisprudence.

\section{Conclusion}

In this article, it has been acknowledged that there are significant institutional difficulties for the ECtHR in establishing anything but the lowest common standards for the protection of vulnerable individuals in welfare needs contexts across 47 member states, each with its own social and political histories and levels of welfare protection. Moreover, significant limitations in the drafting of ECHR rights have also been recognised, by contrast with modern constitutions, such as the African Charter, which spell out the indivisibility of rights, or the South African Constitution, which recognises the tripartite nature of all human rights obligations and affords graduated protection to human rights in accordance with the severity of threats and the availability of resources.

Nevertheless, emphasis has been put on the special responsibilities and expectations that are placed on international courts and monitoring bodies in developing the content of socio-economic rights. ${ }^{124}$ It has been envisaged that when an international court, especially one of such standing as the ECtHR, identifies a latent right in the terms of the Convention, or finds that positive socio-economic consequences flow from the court's interpretation of

121 (2009) 48 EHRR 41.

122 Ibid. para. 81. Moreover, the ECtHR has specifically recognised that the margin of appreciation can cover the sort of nuanced judgments that states may have to make when determining cut-off dates for entitlements to benefits.

123 Stec $\mathrm{v}$ UK (2006) 43 EHRR 47. The difference in pensionable ages of men and women in the UK had been intended to address the economically disadvantaged position of women.

124 See P Alston, "Establishing a right to petition under the Covenant on Economic, Social and Cultural Rights" in Collected Courses of the Academy of European Law (Florence: European University Institute 1993) vol IV, book 2, p. 107, pp. 151-2 with reference to the underdevelopment of the normative content of the rights in the ICESCR. 
substantive ECHR rights, this might break the "vicious circle"125 in which lack of development of human rights norms in socio-economic contexts has inhibited the search for creative and innovative judicial procedures to guarantee their protection. It is not unreasonable to hope that, by entering the field of socio-economic rights, the ECtHR will attempt to give "concrete meaning to mere slogans", turning them into enforceable norms and encouraging national judges to apply them without fear of exceeding the law, a process that has been seen at its best before the UK courts in Bernard ${ }^{126}$ and Limbuela. ${ }^{127}$

However, this paper has suggested that, despite evidence of this valuable interaction, there is room for the ECtHR further to define the scope of positive obligations in order to protect the socio-economic rights of the vulnerable and socially disadvantaged in member states. On the one hand, this would recognise the overlap between civil, political and socioeconomic rights and, on the other hand, it would acknowledge the very different levels of resources by which states might progressively realise the rights. Instead, however, it has been demonstrated that the ECtHR has not only sought to avoid the logic of its own jurisprudence in Articles 3 and 8 ECHR. It has been suggested that the pragmatic attempt at harmonisation through an artificial extension of the substantive socio-economic rights covered by the Convention runs counter to the development of a jurisprudence of positive obligations that fully respects the moral and existential overlap between civil, political and socio-economic rights. This paper therefore has argued that despite some recent departures from a formal equality model in the ECHR jurisprudence, the incremental development of positive obligations in Articles 6 and 14 has inhibited the Convention's evolution as an instrument for the principled resolution of disputes concerning the fair distribution of socio-economic entitlements in member states.

125 De Schutter, "The protection of social rights", n. 13 above, p. 232.

126 [2002] EWHC (Admin) 2282.

127 [2005] UKHL 66, [2009] 1 AC 396. 
